\title{
Efficiency of foliar application of sparingly soluble sources of boron and zinc in citrus
}

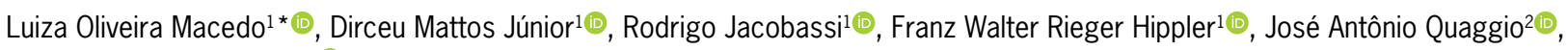 \\ Rodrigo Marcelli Boaretto1(i)
}

\author{
${ }^{1}$ Instituto Agronômico de Campinas/Centro de Citricultura \\ Sylvio Moreira, Rod. Anhanguera, km 158, C.P. 04 - 13490- \\ 970 - Cordeirópolis, SP - Brasil. \\ Instituto Agronômico de Campinas/Centro de Solos e \\ Recursos Ambientais, Av. Barão de Itapura, 1481, C.P. 28 - \\ 13020-902 - Campinas, SP - Brasil. \\ *Corresponding author <luizaoliveiram@hotmail.com>
}

Edited by: Anoop Kumar Srivastava

Received November 14, 2018

Accepted June 17, 2019

\begin{abstract}
This study evaluated leaf supply of zinc $(\mathrm{Zn})$ and boron $(\mathrm{B})$ using either soluble or sparingly soluble fertilizers in young sweet orange trees. Three experiments were set up in a greenhouse to compare two sources and four doses (control, low, adequate and high) of fertilizers as follows: (i) Experiment I (B): boric acid and calcium borate; (ii) Experiment II (Zn): Zn sulfate and Zn oxide; and (iii) Experiment III $(B+Z n)$ : boric acid + Zn Sulfate and Zn Borate. The sparingly soluble sources were effective in increasing the $\mathrm{Zn}$ and $\mathrm{B}$ leaf concentration. Dry matter of the aerial part increased $18 \%$ with $B$ applications in adequate concentration independent of the $B$ fertilizer sources. In contrast, trees did not grow well with applications of adequate concentration of $\mathrm{Zn}$ as $\mathrm{Zn}$ Sulfate or high $\mathrm{Zn}$ concentration as $\mathrm{Zn}$ borate. Superoxide dismutase activity in leaves increased with applications of low concentration of $\mathrm{Zn}$ as $\mathrm{Zn}$ oxide and decreased with high concentration of $\mathrm{Zn}$ from either source. Polyphenol oxidase activity increased with application of adequate concentration of $B$ as boric acid and high concentration of $B$ as calcium borate. Furthermore, the upper concentrations of $\mathrm{Zn}$ were toxic in orange trees when the source was Zn sulfate. Increases in plant growth without damage to leaf tissue and positive responses of key enzymes of orange trees in a range of nutrient concentration applications demonstrated the practical use of sparingly soluble fertilizers to supplying B and Zn foliarily to plants.
\end{abstract}

Keywords: micronutrients, microparticles, leaf spraying, fertilizer use

\section{Introduction}

The majority of orange groves cultivated in acid to neutral $\mathrm{pH}$ soils require frequent supply of $\mathrm{B}$ and $\mathrm{Zn}$, otherwise fruit production is limited (Quaggio et al., 2010; Wang et al., 2015; Mattos Jr. et al., 2017). Leaf application has been an effective and preferred management practice employed by growers for micronutrient fertilization in the field (Fageria et al., 2009; Du et al., 2015), which also considers the convenience of distribution of small amounts of products and mixture with defensives (Fernández et al., 2013). Soluble sulfate, chloride and nitrate micronutrient salts represent the main fertilizer sources utilized for leaf spraying in citrus (Quaggio et al., 2010). However, given incidences of leaf "burning" associated with toxic saline symptoms of more concentrated fertilizer solutions (Fernández et al., 2013), the search for new fertilizer sources, such as oxides and carbonates, has been sought by sustainable production systems (Bell and Dell, 2008; Macedo et al., 2017). Efficiency of traditional foliar fertilizers depends on water solubility, while sparingly soluble sources rely upon particle size, in which the smallest particles 10.2 $20 \mu \mathrm{m}$ ) facilitate the release and further absorption of the nutrient by plant leaves (Du et al., 2015), maintaining a constant nutrient supply for long periods reducing the risk of leaf tissue injury immediately after application (Li et al., 2012).

In addition to the quantification of nutrient concentration in leaves, the analysis of superoxide dismutase activity (SOD) was proposed to study the interaction between metals and plants (Shenker et al., 2004) as $\mathrm{Zn}$ is a constituent of $\mathrm{Cu} / \mathrm{Zn}$-SOD (Hansch and
Mendel, 2009; Hippler et al., 2015a) and may also be indicative of the risk of phytotoxicity in plants supplied with excess micronutrients (Hippler et al., 2015a; Hippler et al., 2018). The activity of polyphenol oxidase (PPO) has been assessed as an indicator of the nutritional status of $\mathrm{B}$ since rises in the concentration of phenols in B-deficient tissues may result from restrictions in the biosynthesis of phenolic alcohols (Marschner, 2011).

Considering the need to validate the efficiency of new micronutrient sources, the present research study was undertaken to test the hypothesis that sparingly soluble sources of $\mathrm{B}$ and $\mathrm{Zn}$, in microparticles, adequately supply these nutrients to the leaves of orange plants compared to soluble sources traditionally used in orchards.

\section{Materials and Methods}

\section{Plant growth conditions and treatments}

Three experiments were carried out in a greenhouse on one-year-old sweet orange trees from cv. Pera [Citrus sinensis (L.) Osbeck] grafted onto Rangpur lime (C. limonia Osbeck). Orange plants were transplanted to 12 $\mathrm{L}$ plastic pots, filled with organic substrate $180 \%$ pine bark, $5 \%$ carbonized materials and $15 \%$ vermiculite), and pruned $40 \mathrm{~cm}$ above the grafting point to induce new vegetative growth.

During the course of the experiment, both macroand micronutrients were applied via a nutrient solution modified according to Hippler et al. (2015b). The supply of macronutrients took place over the course of 40 applications, from transplantation up to 180 days after starting treatments, and micronutrient supply with 
15 applications from starting treatments up to 180 days after, according to the subsequently described experimental characteristics. Before the beginning of the foliar treatment four plants were destructively harvested and the initial leaf area (LA) and dry matter (DM) canopy measures were $0.38 \pm 0.2 \mathrm{~m}^{2}$ and $74 \pm 5.3 \mathrm{~g}$ per plant, respectively. Plants chosen for the application of treatments were uniform at that time.

Treatments in each experiment consisted of the application of two sources of fertilizers, one soluble in water and another sparingly soluble in water $(0.2-20 \mu \mathrm{m}$ particle size) as well as four doses of the micronutrient in a $2 \times 4$ factorial design all together within a completely randomized factorial design replicated four times. Experiment I (B) consisted of foliar application of four doses of B, control (without B), 130, 260 and $520 \mathrm{mg} \mathrm{L}^{-1}$ of $\mathrm{B}$ (in summary $0,13,28$ and $55 \mathrm{mg}$ per plant of total B after 180 days) as soluble source boric acid $\left(\mathrm{H}_{3} \mathrm{BO}_{3}\right)$ or sparingly soluble source calcium borate $\left[\mathrm{CaB}_{3} \mathrm{O}_{4}(\mathrm{OH})_{3} \cdot \mathrm{H}_{2} \mathrm{O}\right]$. Experiment II $(\mathrm{Zn})$ consisted of foliar application of four doses of $\mathrm{Zn}$, control (without $\mathrm{Zn}), 200,600$ and $1800 \mathrm{mg} \mathrm{L}^{-1}$ of $\mathrm{Zn}$ (in summary 0 , $23,65,200 \mathrm{mg}$ per plant of total $\mathrm{Zn}$ after 180 days) as soluble source $\mathrm{Zn}$ sulfate $\left(\mathrm{ZnSO}_{4} \cdot 7 \mathrm{H}_{2} \mathrm{O}\right)$ or sparingly soluble source $\mathrm{Zn}$ oxide ( $\mathrm{ZnO})$. Experiment III (B and $\mathrm{Zn})$ consisted of foliar application of four doses of B + $\mathrm{Zn}$, control (without B and $\mathrm{Zn}$ ), 43, 129 and $387 \mathrm{mg} \mathrm{L}^{-1}$ of B (in summary 5, 14 and $45 \mathrm{mg}$ per plant of total B after 180 days), and correspondent 200, 600 and 1800 $\mathrm{mg} \mathrm{L}^{-1}$ of $\mathrm{Zn}$ (in summary 23, 65, $200 \mathrm{~m}$ g per plant of total $\mathrm{Zn}$ ) as soluble sources boric acid $+\mathrm{Zn}$ sulfate and sparingly soluble source $\mathrm{Zn}$ borate $\left(2 \mathrm{ZnO} 3 \mathrm{~B}_{2} \mathrm{O}_{3} \cdot 3.5 \mathrm{H}_{2} \mathrm{O}\right)$. The sources $\mathrm{Ca}$ borate, $\mathrm{Zn}$ oxide, and $\mathrm{Zn}$ borate, used as sparingly soluble sources for foliar treatment, had particle dispersion between $0.37 \mu \mathrm{m}$, smaller particle in $\mathrm{Zn}$ oxide, and $18.3 \mu \mathrm{m}$ greater particles in $\mathrm{Zn}$ borate. All sources were characterized as microparticulates and contained flowable technology adjuvant for retention of the microparticles in leaves. An adjuvant featuring 200 $\mathrm{g} \mathrm{L}^{-1}$ of nonyl phenoxy poly (ethyleneoxy) ethanol was mixed at $0.1 \mathrm{ml} \mathrm{L}^{-1}$ with the treatment solution of the soluble sources. Doses of nutrients in each experiment were defined based on the adequate concentration levels recommended for citrus orchards by Quaggio et al. (2010), with two additional doses in each experiment as follows - for B (Experiment I) : a half and double of the adequate level; for $\mathrm{Zn}$ (Experiment II): a third of and triple the adequate level; and for B and Zn (Experiment III): a third of and triple the adequate level of $\mathrm{Zn}$ and doses of $\mathrm{B}$ were adjusted based on the adequate dose of $\mathrm{Zn}$. Three treatments were applied - in the first flush of orange vegetation, 160 days after the transplant of trees, and the other two at 60-day intervals, coinciding with the second and third flushes of vegetative growth of trees. At the moment of foliar spraying, a plastic cover was placed on the surface of pots to avoid contamination of the substrate with sprayed solutions. The amounts of solution applied were approximately $25 \mathrm{~mL}$ per plant in the first application, $45 \mathrm{~mL}$ per plant in the second application and $50 \mathrm{~mL}$ per plant in the third application, which were proportional to the LA of plants during every period to guarantee uniform coverage of the leaf surface with a sprayed solution. After the applications, the total amounts of micronutrient retained per plant were estimated for each treatment.

\section{Dry matter production and chemical analysis of plant material}

The aerial part of plants was destructively harvested 60 days after the last foliar application in Experiments I (B), II ( $\mathrm{Zn})$, and III (B and $\mathrm{Zn})$, and separated into leaves and woody parts (stem + branches). After collection of the plants, before the leaves were dried and processed, LA was measured using the leaf area integrator (LI-COR 3100). The harvested plant material was washed in $5 \%$ diluted detergent and distilled water (Alva and Tucker, 1997) and oven dried at $65^{\circ} \mathrm{C}$ to constant weight for quantification of the DM. Leaves and woody parts were ground in a Willey-type mill for determination of plant nutrient concentrations by chemical analysis according to Bataglia et al. (1983).

\section{Enzymatic analysis}

Plants in Experiments I (B) and II (Zn) developed new shoots from the main stem after the harvesting of aerial parts in the first part of the experiment, where enzymatic activity analysis was performed on the leaves. During this new period, ten maintenance fertilizations with micro- and macronutrient were applied via a nutrient solution modified according to Hippler et al. (2015b). Completely expanded and mature leaves developed 70 days after harvest, which then received a new foliar application of treatments that was repeated after another 70 days following the first application. The volume of solution applied was approximately 25 $\mathrm{mL}$ per plant for both the first and second applications. Amounts of B applied to plants with both fertilizer sources in Experiment I (B) were 0, 6.5, 13, and $26 \mathrm{mg}$ per plant of B. With this, the amounts of $\mathrm{Zn}$ applied to plants from both sources in Experiment II (Zn) were 0, 10,30 , and $90 \mathrm{mg}$ of $\mathrm{Zn}$ per plant.

Four mature leaves per plant were collected seven days after the second foliar treatment application. The leaves sampled were washed with distilled water to avoid contamination of metals present on the surface, then immediately placed in liquid nitrogen, and subsequently stored in an ultra-freezer at $-80^{\circ} \mathrm{C}$ until protein extraction.

Extraction of total protein was conducted according to Gomes Jr. et al. (2006). For determination of total protein according to the method adopted by Bradford (1976), $20 \mu \mathrm{L}$ of the 10 -fold diluted aliquot of each sample was added to $1.0 \mathrm{~mL}$ of Bradford's solution. Optical density (absorbance) of samples was determined in a spectrophotometer at $595 \mathrm{~nm}$. Bovine serum albumin (BSA) was used as a standard. 
SOD activity was determined by electrophoresis according to Gomes Jr. et al. (2006) via polyacrylamide gel (polyacrylamide gel electrophoresis; PAGE) at $12 \%$ $(\mathrm{m} / \mathrm{v})$. The gels were documented in an Image Scanner. The isoforms of SOD, Cu/Zn-SOD, Fe-SOD, or Mn-SOD were determined by gel electrophoresis according to Hippler et al. (2016).

PPO activity was evaluated following the method adopted by Kar and Mishra (1976). The activity was estimated by measuring absorbance at $420 \mathrm{~nm}$ over 1 min. One unit of PPO activity was defined as the amount of enzyme that caused an increase in absorbance of 0.001 $\min ^{-1}$ to $1 \mathrm{~mL}$ of the enzyme and per $\mathrm{mg}$ of protein at $25^{\circ} \mathrm{C}$.

Leaves collected after growth of new shoots were washed with $5 \%$ diluted detergent and distilled water (Alva and Tucker, 1997), dried in an oven at $65^{\circ} \mathrm{C}$, and ground in a Willey-type mill to determine the concentration of nutrients (Bataglia et al., 1983).

\section{Statistical analysis}

Data collected for greenhouse or laboratory assays were submitted to analysis of variance, and means were analyzed statistically by the $\mathrm{F}$ test $(p<0.05)$ using SISVAR (Variance Analysis System, version 5.3). Regression equations were estimated for the parameters that were significant according to the $\mathrm{F}$ test for dose or interaction between source and dose $(p<0.05)$.

\section{Results}

\section{Plant nutritional status, growth and biomass production}

Leaf concentrations of B and $\mathrm{Zn}$ increased with doses of soluble and sparingly soluble fertilizers sources sprayed on plants in experiments I (B), II (Zn) and III (B and $\mathrm{Zn}$ ). In the woody parts, B concentration increased only with calcium borate while $\mathrm{Zn}$ concentration rose as a result of the highest doses of either the soluble $(\mathrm{Zn}$ sulfate) or sparingly soluble ( $\mathrm{Zn}$ oxide and $\mathrm{Zn}$ borate) fertilizer sources (Figure 1). Furthermore, calcium borate at $520 \mathrm{mg} \mathrm{L}^{-1}$ provided the highest $\mathrm{B}$ concentration in the leaves $\left(97 \mathrm{mg} \mathrm{kg}^{-1}\right), 44 \%$ above the level obtained with boric acid, as well the highest B concentration in the woody parts $\left(12 \mathrm{mg} \mathrm{kg}^{-1}\right)$ of trees at the same dose. No differences were observed in Ca concentration in the leaf owing to the calcium borate sprayed on (data not shown). ZnO had the highest $\mathrm{Zn}$ concentration in the leaves $\left(375 \mathrm{~g} \mathrm{~kg}^{-1}\right)$ and woody parts $\left(55 \mathrm{~g} \mathrm{~kg}^{-1}\right)$ when the highest dose was applied, though it was $56 \%$ higher in the leaves compared to $\mathrm{Zn}$ sulfate with the same dose. In corroboration of Experiments I (B) and II (Zn), the sparingly soluble source ( $\mathrm{Zn}$ borate) resulted in a higher leaf concentration of $\mathrm{Zn}\left(256 \mathrm{~g} \mathrm{~kg}^{-1}\right)$ at high doses, and, in contrast, the soluble source provided a higher leaf concentration of B $\left(53 \mathrm{~g} \mathrm{~kg}^{-1}\right)$ with the high dose $(387 \mathrm{mg}$ $\mathrm{L}^{-1}$. In the woody parts of the plants of Experiment III, the $\mathrm{Zn}$ concentration was the same for both sources with a value of $33 \mathrm{~g} \mathrm{~kg}^{-1}$ at the highest dose (Figure 1).
The DM of canopy and LA in Experiment I increased to the adequate dose and decreased until the highest dose showed no noticeable difference between sources. The maximum LA and DM of leaves and canopy were reached at a dose of $295 \mathrm{mg} \mathrm{L}^{-1}$. The leaf DM and LA were the parameters with the greatest variations, specifically a reduction of $18 \%$ with the deficiency dose and $5 \%$ with the excess (Figure 2).

In Experiment II, orange plants sprayed with $\mathrm{ZnO}$ exhibited an increase in the DM of leaves, woody parts, canopy and LA when compared to controls, and this rise occurred with a dose lower than that considered adequate - leaves presenting a concentration of $169 \mathrm{mg} \mathrm{kg}^{-1} \mathrm{Zn}$ and absent any symptoms of toxicity. These symptoms were even more severe at the high dose, when the leaf concentration reached $375 \mathrm{mg} \mathrm{kg}^{-1}$ of $\mathrm{Zn}$. The maximum leaf DM was obtained with a foliar solution containing 428 $\mathrm{mg} \mathrm{L}^{-1}$ of $\mathrm{Zn}$. The plants that received leaf spraying with Zn sulfate had a reduction in DM throughout the whole canopy at the lowest $\mathrm{Zn}$ dose, and a foliar concentration of $60 \mathrm{mg} \mathrm{kg}^{-1}$, the DM remaining constant up through to the high dose, for which the leaf concentration was $164 \mathrm{mg}$ $\mathrm{kg}^{-1}$. With the $\mathrm{ZnO}$ source, there was a reduction of $5 \%$ in DM of leaves under deficiency conditions up to $32 \%$ with excess. For $\mathrm{Zn}$ sulfate, the decrease in leaf DM from the control treatment at the highest dose was $17 \%$ (Figure 2).

The plants sprayed with doses of $\mathrm{B}$ and $\mathrm{Zn}$ (Experiment III) experienced an increase in DM of the canopy and LA with adequate doses, with a reduction at the highest dose. When the $\mathrm{Zn}$ borate source was used, the plants had maximum DM production of canopy and LA with a dose of $930 \mathrm{mg} \mathrm{L}^{-1} \mathrm{Zn}$ and $200 \mathrm{mg} \mathrm{L}^{-1}$ B. Application of $\mathrm{Zn}$ sulfate and boric acid together resulted, on average, in maximum DM production by the plants, at doses of $1500 \mathrm{mg} \mathrm{L}^{-1} \mathrm{Zn}$ and $290 \mathrm{mg} \mathrm{L}^{-1}$ B. The DM of the canopy decreased by $20 \%$ in cases of deficiency for both sources. For the $\mathrm{Zn}$ borate source, it decreased $18 \%$ in excess, whereas for the soluble source, there was no decrease in excess (Figure 2). The correlations between the leaf concentration and the production of DM of the canopy in Experiment III (B and $\mathrm{Zn}$ ) (Figure 3) shows that the limit for toxicity in this experiment was $150 \mathrm{mg} \mathrm{kg}^{-1}$ considering that the regression equation exhibited the highest DM for both sources ( $\mathrm{Zn}$ oxide and $\mathrm{Zn}$ sulfate) at this dose (Figure 3).

\section{Symptoms of toxicity owing to salt excess}

Orange plants that received foliar spray with the highest dose of $\mathrm{Zn}$ sulfate $\left(1800 \mathrm{mg} \mathrm{L}^{-1}\right.$ of $\mathrm{Zn}$ ) in Experiments II and III exhibited symptoms of toxicity because of the high salt content of the soluble fertilizer, characterized by yellowish sores that in the leaf limb, mainly on young leaves (Figure 4C, D, G and H). However, those plants sprayed with the highest dose of $\mathrm{Zn}$, albeit with the sources of $\mathrm{Zn}$ oxide and $\mathrm{Zn}$ borate did not demonstrate symptoms of toxicity and featured deposition of the microparticulate sparingly soluble fertilizer (Figure 4A, B, E and F). 

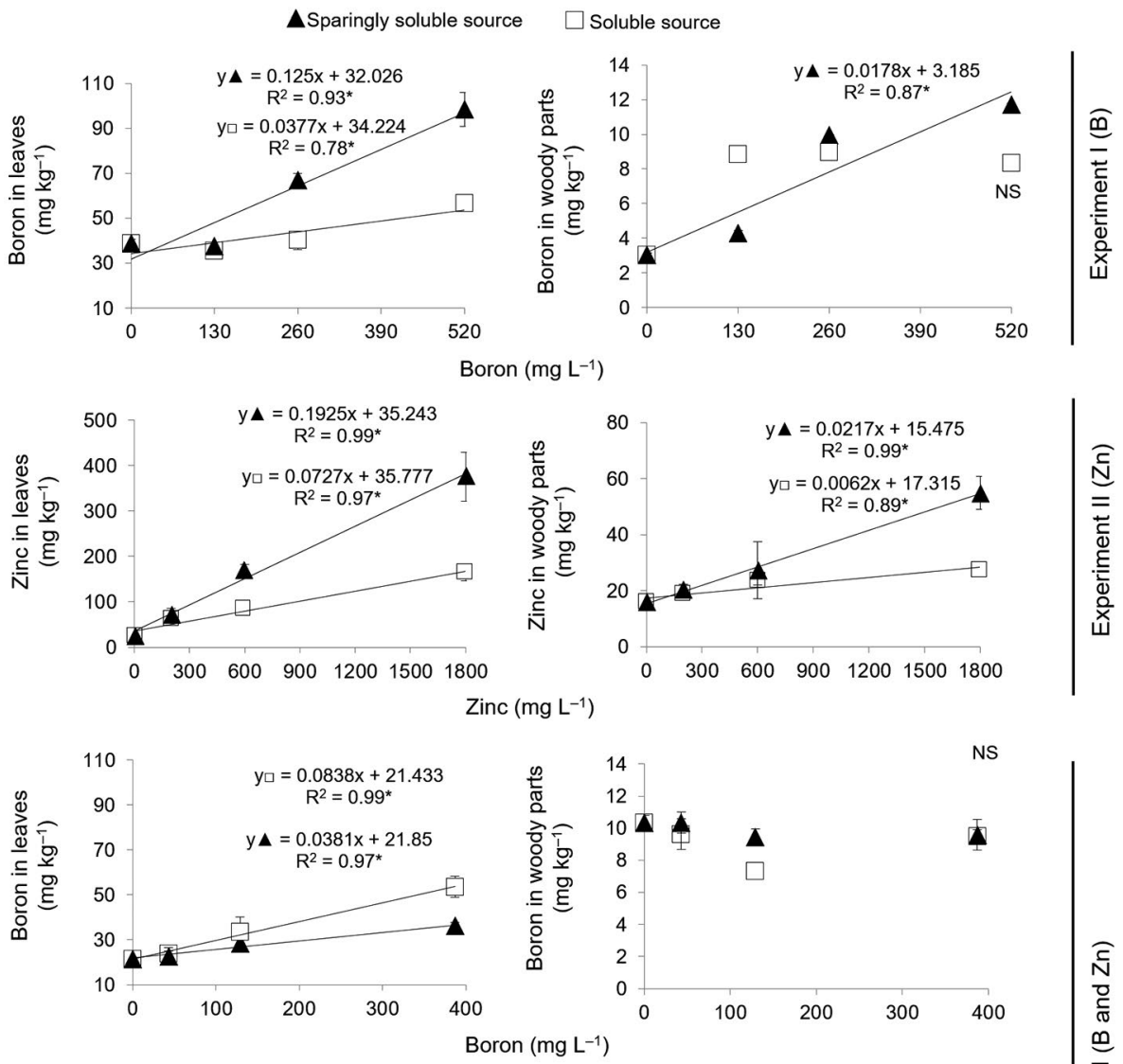

S
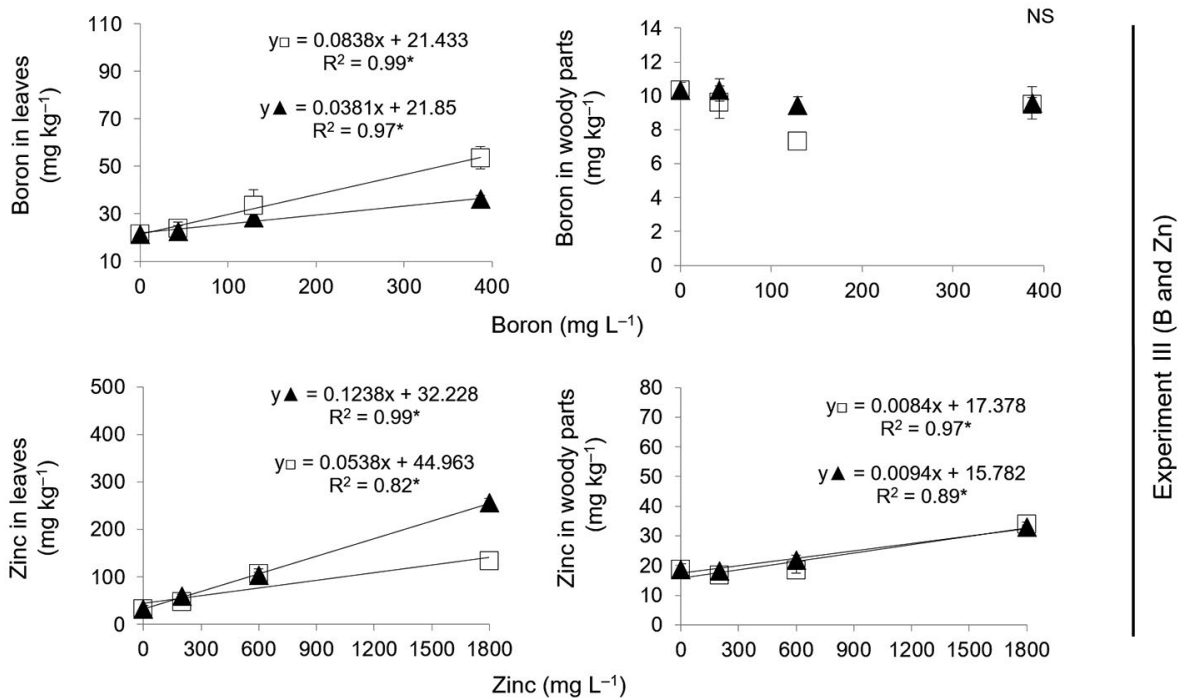

Figure $1-Z n$ and B concentrations in the leaves and woody parts of young orange plants sprayed with soluble and sparingly soluble sources of $\mathrm{Zn}$ and $\mathrm{B}$ at increasing concentrations harvested after 60 days since the last application. Experiment I (B), Experiment II (Zn) and Experiment III $(B$ and $Z n)$. Vertical lines represent the standard error of the mean $(n=4)$. Legend: * Significant at $1 \%$; Nsnot significant at $5 \%$ according to the $F$ test.

\section{Enzyme activity}

Four isoforms of SOD were identified in the leaves of orange plants receiving varying doses of $\mathrm{B}$ and $\mathrm{Zn}$ : Three $\mathrm{Cu} / \mathrm{Zn}-\mathrm{SOD}$ (I, II and III) and two Mn-SOD (I and II). In Experiment I (B), the control plants, without application of $\mathrm{B}$, showed low $\mathrm{Cu} / \mathrm{Zn}$ SOD isoform activity with leaf concentrations of 35 $\mathrm{mg} \mathrm{kg}^{-1} \mathrm{~B}$. When the application of $\mathrm{B}$ was carried out with calcium borate, the activity of the $\mathrm{Cu} / \mathrm{Zn}$-SOD isoform increased from the lowest dose $\left(130 \mathrm{mg} \mathrm{L}^{-1}\right.$ of B) to the highest dose $\left(520 \mathrm{mg} \mathrm{L}^{-1}\right.$ of B) with a leaf concentration from $44 \mathrm{mg} \mathrm{kg}^{-1}$ up to $70 \mathrm{mg} \mathrm{kg}^{-1}$. The $\mathrm{Cu} / \mathrm{Zn}$-SOD isoform with the 130 and $260 \mathrm{mg} \mathrm{L}^{-1}$ doses of $\mathrm{B}$, with leaf concentration of $48 \mathrm{mg} \mathrm{kg}^{-1}$ and $58 \mathrm{mg}$ $\mathrm{kg}^{-1}$, respectively, when applied in the form of boric acid, presented similar activity to the dose of $520 \mathrm{mg}$ $\mathrm{L}^{-1}$ of $\mathrm{B}$ in the form of calcium borate. At the highest dose of $\mathrm{B}$ as boric acid, when the B foliar concentration was $89 \mathrm{mg} \mathrm{kg}^{-1}$, the activity of the $\mathrm{Cu} / \mathrm{Zn}$-SOD isoform experienced a minor decrease compared to the two lower doses. The Mn-SOD isoform's activity was not affected based on the doses and sources of $\mathrm{B}$ applied (Figure 5A).

In Experiment II (Zn), the control plants, without application of $\mathrm{Zn}$, when the foliar concentration was $12 \mathrm{mg} \mathrm{kg}$, presented low $\mathrm{Cu} / \mathrm{Zn}-\mathrm{SOD}$ (II and III) 


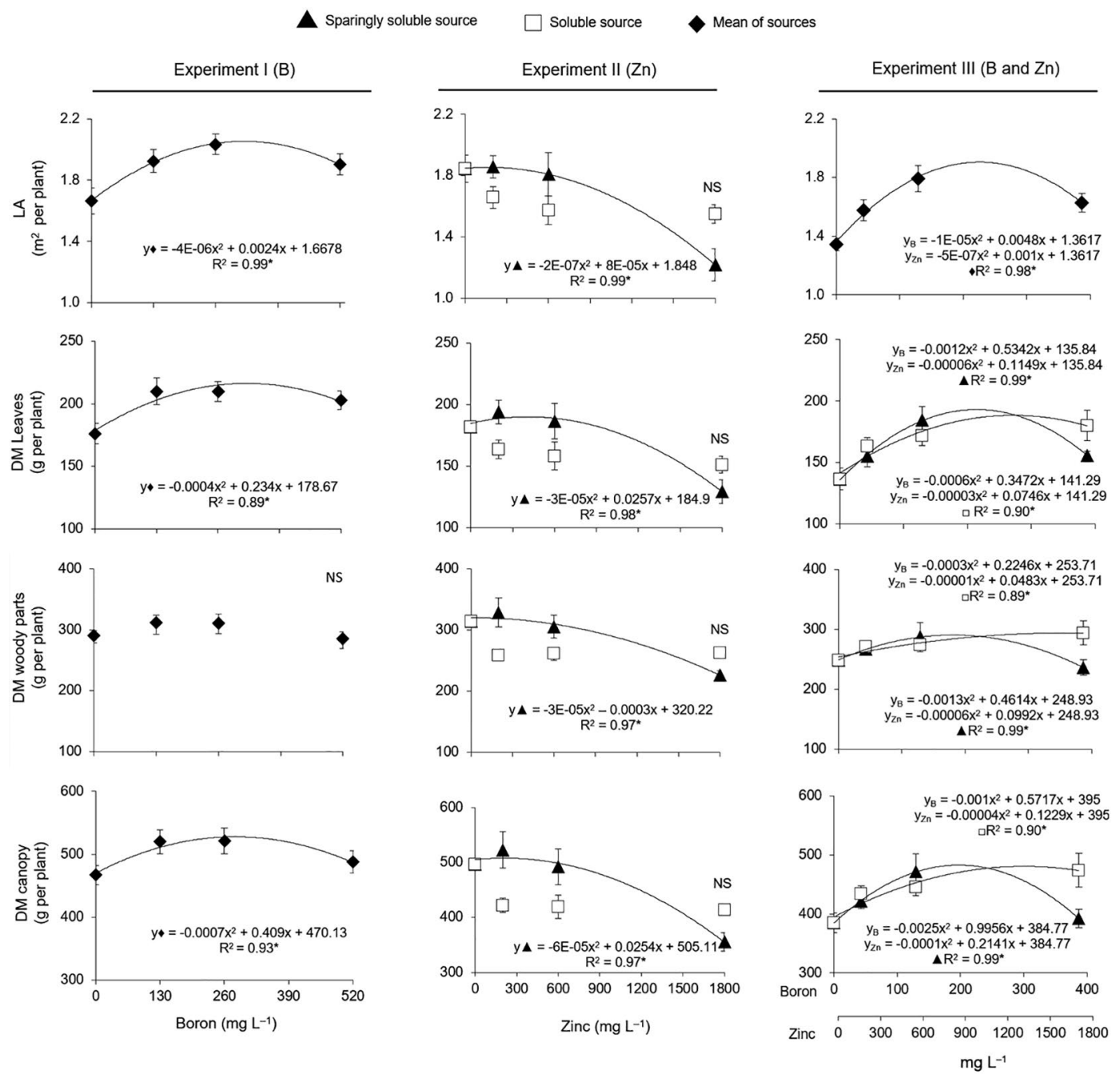

Figure 2 - Leaf area (LA) and dry matter (DM) of leaves, woody parts, and canopy of young orange plants sprayed with soluble and sparingly soluble sources of $\mathrm{Zn}$ and $\mathrm{B}$ at increasing concentrations harvested after 60 days since the last application. Experiment I (B), Experiment II (Zn) and Experiment III (B and $\mathrm{Zn})$. Vertical lines represent the standard error of the mean $(n=4)$. Legend: * Significant at $5 \%$; Nsnot significant at $5 \%$ according to the $\mathrm{F}$ test.

isoform activity. With the application of $\mathrm{ZnO}$, the $\mathrm{Cu}$ / $\mathrm{Zn}$-SOD isoform had a decrease in activity from the low dose to the higher dose, with Zn leaf concentration varying from $29 \mathrm{mg} \mathrm{kg}^{-1}$ up to $133.5 \mathrm{mg} \mathrm{kg}^{-1}$. The same pattern was noted with the application of $\mathrm{Zn}$ sulfate, where the activity decreased from the smallest $\mathrm{Zn}$ leaf concentrations $\left(27 \mathrm{mg} \mathrm{kg}^{-1}\right)$ up to the highest (114 mg $\left.\mathrm{kg}^{-1}\right)$. The activity of the $\mathrm{Cu} / \mathrm{Zn}$-SOD isoform was greater in the leaves of the plants that received $\mathrm{Zn}$ sulfate spraying at all doses when compared to the activity in the leaves that received $\mathrm{Zn}$ oxide. The Mn-SOD isoform exhibited higher activity at doses of 600 and $1800 \mathrm{mg} \mathrm{L}^{-1}$ Zn (Figure 5B).

The PPO activity in orange leaves that received the soluble source, boric acid increased $38 \%$ in control plants, without application of $B$, up to a dose of $334 \mathrm{mg}$ $\mathrm{L}^{-1}$ of $\mathrm{B}$, with a subsequent decrease $(12 \%)$ at the highest dose of B. When sprayed with the calcium borate source, PPO activity rose $29 \%$ with the control dose up to the highest dose of $\mathrm{B}$. The highest activity of PPO with the application of boric acid was $11 \%$ more than the highest activity achieved with the application of calcium borate (Figure 6).

\section{Discussion}

Our study evaluated the use of B and $\mathrm{Zn}$ applied foliarly to young orange trees as sparingly soluble fertilizer sources in comparison with soluble fertilizers commonly recommended for orchard nutrient management. Effects of nutrient supply to plants were measured via plant tissue chemical analyses, DM yield, LA, and the activity of selected enzymes on leaf tissue. The positive effects of leaf application of $\mathrm{B}$ and $\mathrm{Zn}$ on 
nutritional status, retention of leaves, yield and fruit quality of citrus trees have been observed previously (Dawood et al., 2001; Eman et al., 2007; Razzaq et al., 2013), fostering the use of new fertilizer sources in commercial orchards (Bell and Dell, 2008).

The sparingly soluble sources (Zn oxide, calcium borate and $\mathrm{Zn}$ borate) tested in the experiments were effective in increasing the $\mathrm{Zn}$ and $\mathrm{B}$ leaf concentration of orange trees according to the increase in nutrient doses (Figure 1). We were able to verify that the sparingly soluble sources provided the highest leaf concentration of B in Experiment I $\left(97 \mathrm{mg} \mathrm{kg}^{-1}\right)$ as well as $\mathrm{Zn}$ in Experiments II (375 $\left.\mathrm{mg} \mathrm{kg}^{-1}\right)$ and III $\left(256 \mathrm{~g} \mathrm{~kg}^{-1}\right)$, suggesting that although less soluble than the sulfate and boric acid, when used as microparticles, these fertilizers promoted effective absorption through the nutrients applied to the leaves after dissolution of the particles (Westfall et al., 1999; Du et al., 2015).
The amount of $\mathrm{B}$ and $\mathrm{Zn}$ absorbed in each experiment was correlated with the DM of the aerial parts of plants. Although the concentration of B in leaves sprayed with calcium borate was higher than that which received boric acid (Figure 1), the LA and DM of both the leaves and the canopy did not vary with the sources tested (Figure 2). Plants exhibited maximum DM and LA with $295 \mathrm{mg} \mathrm{L}^{-1}$ of B in Experiment I (Figure 2), which was in accordance with the response of plants in the field when sprayed with the recommended doses of 200 to $300 \mathrm{mg} \mathrm{L}^{-1}$ of B, considered adequate for citrus (Quaggio et al., 2010) and usually applied as boric acid. The lack of difference in DM production of plants resulted from different fertilizer sources, demonstrating that foliar application of $\mathrm{B}$, when using a microparticulated sparingly soluble source, supplies the required amounts of nutrients necessary for normal physiological plant processes compared with the use of a soluble source.
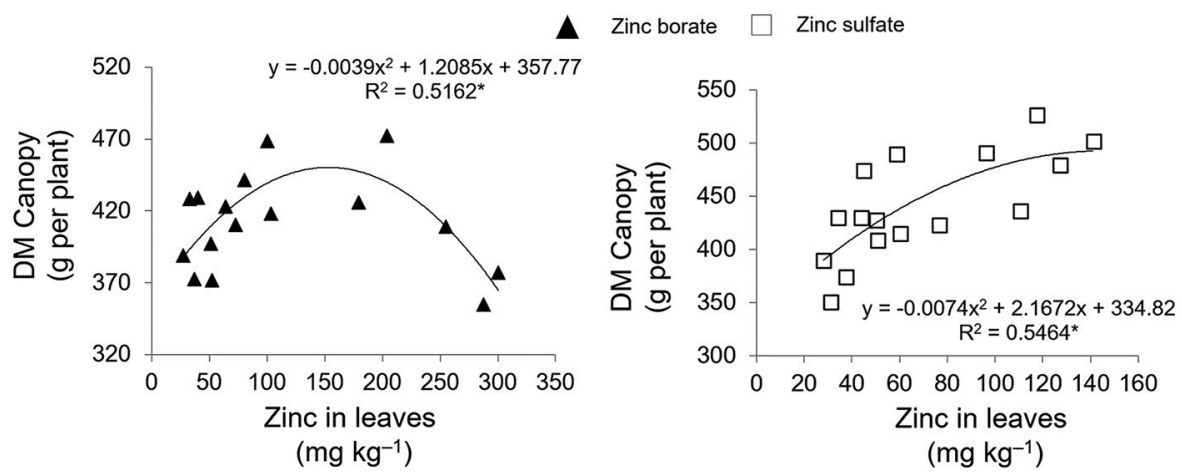

Figure 3 - Correlation between $\mathrm{Zn}$ concentration in the leaves and DM mass of the canopy of plants sprayed with $\mathrm{Zn}$ borate and $\mathrm{Zn}$ sulfate together with boric acid with young orange plants sprayed three times at varying $\mathrm{Zn}$ and B concentrations harvested after 60 days since the last application. Legend: *Significant at $5 \%$.

Experiment II (Zn)

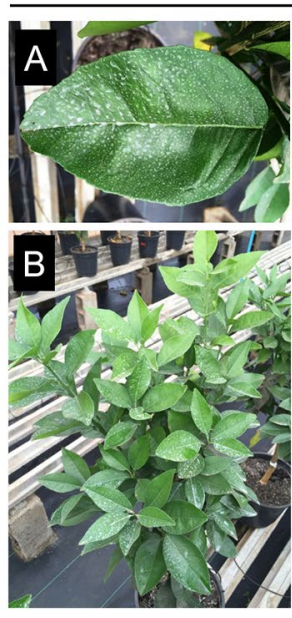

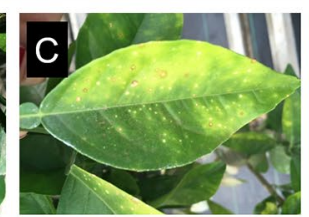

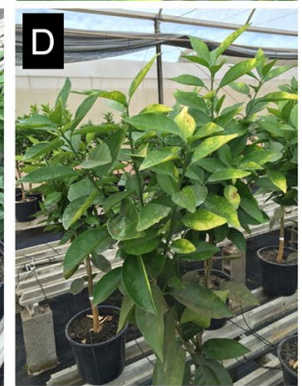

Experiment III (B and Zn)
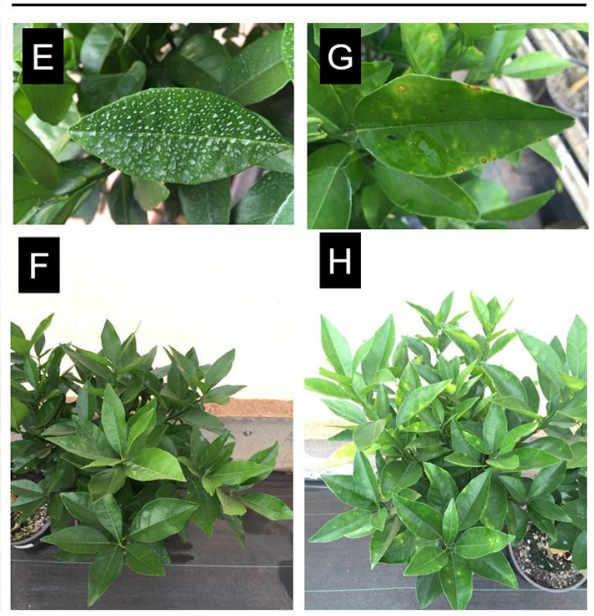

Figure 4 - Young leaf of orange applied with $Z n$ oxide (A), upper view of young orange plant applied with Zn oxide (B), young leaf of orange applied with Zn sulfate (C), upper view of young orange plant applied with Zn sulfate (D), young leaf of orange applied with Zn borate (E), upper view of young orange plant applied with Zn borate (F), young leaf of orange applied with Zn sulfate and boric acid (G), and upper view of young orange plant applied with $\mathrm{Zn}$ sulfate and boric acid $(\mathrm{H})$. 


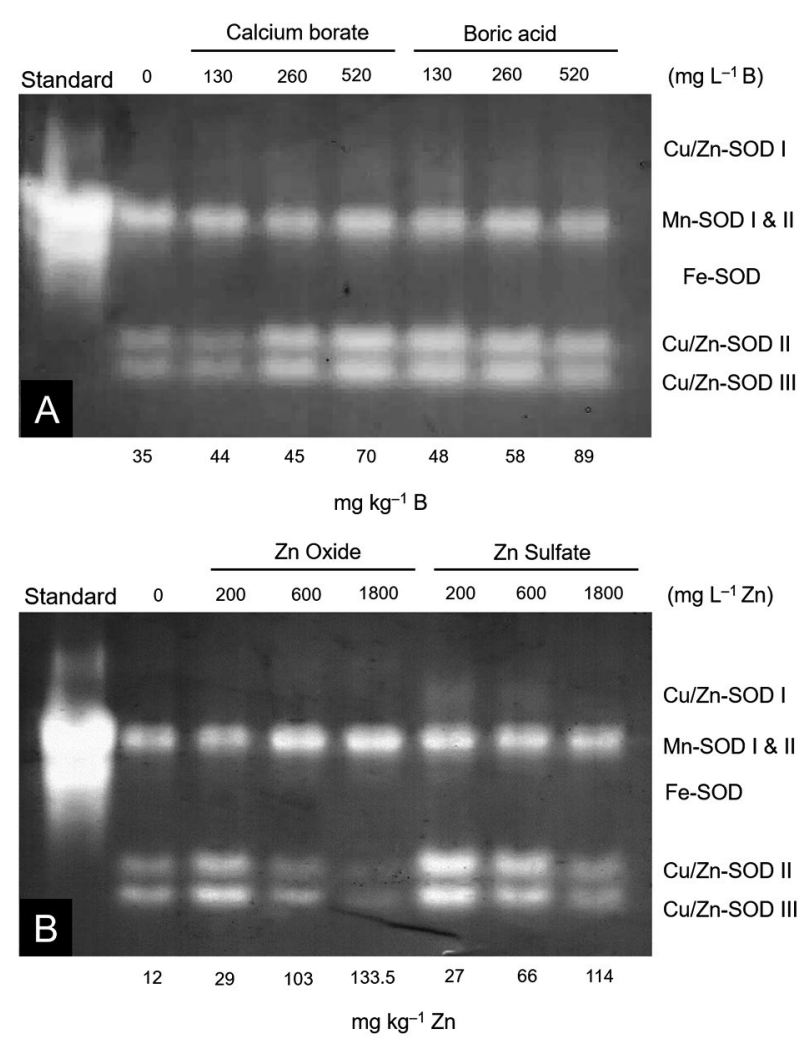

Figure 5 - SOD activity in PAGE (12\%) in leaves of young orange plants sprayed twice with varying concentrations and sources of $B$ (A) and $\mathrm{Zn}(\mathrm{B})$ harvested after seven days since the last application. Legend: more abundant white bands represent greater activity of the enzyme.

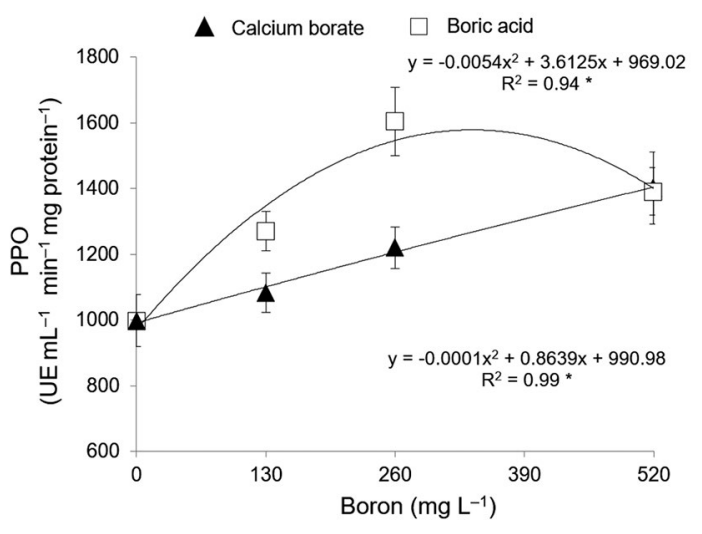

Figure 6 - PPO activity in leaves of young orange plants sprayed twice with varying $B$ concentrations harvested after seven days since the last application. Vertical lines represent the standard error of the mean $(n=3)$. Legend: * Significant at $5 \%$ according to the $\mathrm{F}$ test.

High doses of B applied as calcium borate and boric acid did not result in high concentrations of foliar $\mathrm{B}$ as has been found in other works with doses of $\mathrm{B}$ above $300 \mathrm{mg} \mathrm{L}^{-1}$ (Quaggio et al., 2010; Ullah et al., 2012; Khan et al., 2015). A low concentration of B in the leaves (40 $\mathrm{mg} \mathrm{kg}^{-1}$ of B) was observed when the lowest dose in this study was applied and, compared to the maximum DM reached with $295 \mathrm{mg} \mathrm{L}^{-1}$ of $\mathrm{B}$, reflected a decrease in DM (18\%), characterized as a nutritional deficiency by Mesquita et al. (2016). At the highest dose of B tested, no significant nutrient toxicity was observed, represented by just a $5 \%$ decrease in the DM of the aerial part. This is likely explained by the medium concentration of B (97 $\mathrm{mg} \mathrm{kg}^{-1}$ ) seen in the leaves. Excess B might reduce up to $50 \% \mathrm{DM}$ of citrus trees, associated with a decreased net assimilation rate of $\mathrm{CO}_{2}$ and leaf transpiration when leaf B concentration $>300 \mathrm{mg} \mathrm{kg}^{-1}$ (Quaggio et al., 2003; Mesquita et al., 2016; Simón-Grao et al., 2018), a limit considered toxic to citrus seedlings based on Mattos Jr. et al. (1995).

Research results on citrus trees that received adequate doses of $\mathrm{Zn}$ sulfate described leaf concentrations in the order of $100 \mathrm{mg} \mathrm{kg}^{-1} \mathrm{Zn}$, levels that did not induce plant toxicity (Tariq et al., 2007; Khan et al., 2015). However, concentrations > $100 \mathrm{mg}$ $\mathrm{kg}^{-1}$ caused toxicity in citrus (Obreza and Morgan, 2008; Hippler et al., 2015a). We found in Experiment III, with the application of $\mathrm{Zn}$ borate and $\mathrm{Zn}$ sulfate, that $150 \mathrm{mg}$ $\mathrm{kg}^{-1}$ of $\mathrm{Zn}$ in leaves is the threshold limit for toxicity (Figure 3). Plants supplied with Zn borate exhibited DM reduction from $150 \mathrm{mg} \mathrm{kg}$-1 $\mathrm{Zn}$ up to $300 \mathrm{mg} \mathrm{kg}^{-1}$ doses of $\mathrm{Zn}$, while the plants supplied with $\mathrm{Zn}$ sulfate presented no reduction in DM because they failed to reach $150 \mathrm{mg} \mathrm{kg}^{-1}$ of $\mathrm{Zn}$ in the leaves (Figure 3).

In Experiment II, $\mathrm{ZnO}$ led to high concentrations of $\mathrm{Zn}\left(169 \mathrm{mg} \mathrm{kg}^{-1} \mathrm{Zn}\right.$ ) in leaves with adequate doses of the nutrient (Figure 1). A severe reduction in DM production of plants (32\%) was observed when the highest doses of $\mathrm{Zn}$ were administered, which correlated with leaf concentrations of approximately $375 \mathrm{mg} \mathrm{kg}^{-1}$ of $\mathrm{Zn}$ (Figure 2). Similarly, a decrease in DM production of plants $(18 \%)$ was observed with application of the highest dose of $\mathrm{Zn}$ borate, which correlated with a foliar concentration of $256 \mathrm{mg} \mathrm{kg}^{-1} \mathrm{Zn}$ (Figures 1 and 2). The reduction in canopy DM at the lowest $\mathrm{Zn}$ doses, when the application was administered with $\mathrm{Zn}$ sulfate in Experiment II (Zn) (Figure 2), likely occurred because of the amount of salt present in the spraying solution prepared with soluble sources, which caused injury after rapid leaf nutrient absorption, especially during the first application when tissues of plants were young, generating an initial delay in growth (Du et al., 2015).

During the second period of evaluation of the experiments (after harvesting of the aerial part and subsequent growth of new shoots from the main stem), the application of $\mathrm{Zn}$ sulfate caused plant injuries characterized by tissue burn of new orange leaves (Figure $4 \mathrm{C}, \mathrm{D}, \mathrm{G}$ and $\mathrm{H}$ ), probably as a consequence of a cell rupture resulting from differences in osmotic pressure across the cell wall when a solution of fertilizers with high salt content was applied to the leaf surface (Clapp, 2009). This symptom was not observed in plants sprayed 
with either $\mathrm{ZnO}$ or $\mathrm{Zn}$ borate as with the use of sparingly soluble fertilizers, particles adhering to the leaf surface serve as a solid phase to restore micronutrient contents to the plant for a longer time, establishing lower absorption immediately after sprays compared to soluble sources (Peryea, 2006; Li et al., 2012; Du et al., 2015).

A research tool that can assist in assessing the absorption and efficiency of applied nutrients is biochemical tissue testing, which compares the activity of an enzyme in a problem sample with a standard sample. In general, three species of SOD in plants are known and their activity is dependent upon a metal cofactor - MnSOD, Fe-SOD, and Cu/Zn-SOD (Shenker et al., 2004). In this study, we investigated the relationship between $\mathrm{Zn}$ supply and $\mathrm{Cu} / \mathrm{Zn}$-SOD enzyme activity and differences noted between soluble and sparingly soluble fertilizer sources and doses (Figure 5B). The lower activity of the $\mathrm{Cu} / \mathrm{Zn}$-SOD II and III isoforms were found in the control treatment when the $\mathrm{Zn}$ concentration in the leaves was < $12 \mathrm{mg} \mathrm{kg}^{-1} \mathrm{Zn}$, a deficient concentration in citrus leaves (Quaggio et al., 2010), owing to the necessity of $\mathrm{Zn}$ as a co-factor for enzyme activation (Hippler et al., 2015a, b). At foliar doses of 200 and $600 \mathrm{mg} \mathrm{L}^{-1}$ of $\mathrm{Zn}$ applied as $\mathrm{Zn}$ sulfate, the $\mathrm{Cu} / \mathrm{Zn}$-SOD II and III isoforms were more active compared to the same doses of $\mathrm{ZnO}$ application (Figure 5B), and this could be expected because of the high initial absorption that occurs with the application of soluble salt sources, especially in young plant tissues. High nutrient absorption causes an imbalance in plant metabolism, impairing the photosynthetic apparatus, generating reactive oxygen species (ROS). Consequently, the activation of SOD enzymes is necessary for the inactivation of these free radicals (Hou et al., 2007; Hippler et al., 2015a, b).

When the applications of $\mathrm{Zn}$ oxide and $\mathrm{Zn}$ sulfate provided a concentration of $\mathrm{Zn}$ in the leaves $>100$ $\mathrm{mg} \mathrm{kg} \mathrm{kg}^{-1}$ (Figure 5B), considered excessive for citrus, especially for young plants (Obreza and Morgan, 2008; Hippler et al., 2015a), decreases in the activity of the $\mathrm{Cu}$ / Zn-SOD II and III isoforms were observed. High levels of metals, such as $\mathrm{Zn}$, can increase the generation of ROS as excess metal levels affect the structure of chlorophyll (Hou et al., 2007) and cause the inhibition of the uptake and transport of other metallic micronutrients in the cells as well as the impairment of the foliar capacity for the synthesis of pigments through the alteration of the protein composition of photosynthetic membranes (Hou et al., 2007; Gratão et al., 2005; 2008). Decreases in the $\mathrm{Cu} / \mathrm{Zn}$-SOD II and III isoform activities in this study (Figure 5B), when the $\mathrm{Zn}$ content was excessive, corroborated the proposal that SOD activity in leaves increases under moderate and low stress, but above a certain level of stress, inactivation and degradation of SOD prevails (Casano et al., 1997; Panda and Patra, 2000).

The reduction in $\mathrm{Cu} / \mathrm{Zn}$-SOD II and III isoform activities at the two higher doses of $\mathrm{ZnO}$ may have been induced partially by the contribution of the competition between $\mathrm{Zn}$ and $\mathrm{Cu}$. With a high foliar concentration of $\mathrm{Zn}$, the transport of the $\mathrm{Cu}$ to the membrane of thylakoids, where isoforms II and III of $\mathrm{Cu} / \mathrm{Zn}$-SOD are found, can be compromised, and without $\mathrm{Cu}$, activation of the enzyme does not take place as it is dependent on both $\mathrm{Zn}$ and $\mathrm{Cu}$ (Figure 5B). This competition would also have consequences for the activity of Mn-SOD, which at the same doses, elevates activity as a way of fostering the inactivation of $\mathrm{Cu} / \mathrm{Zn}$ SOD (Gratão et al., 2005).

As the $\mathrm{Cu} / \mathrm{Zn}$-SOD enzyme was used to investigate the nutritional status of $\mathrm{Zn}$ in citrus, the biochemical test of the PPO enzyme was employed to evaluate the supply of $\mathrm{B}$ in this work. It is known that $\mathrm{B}$ has the ability to complex with free phenolic compounds and that increases in phenol concentration in B-deficient tissues may lead to the activation of PPO, which processes the hydroxylation of monophenols in diphenols and the oxidation of these diphenols to o-quinones. However, it has been shown that the activity of the enzyme is also expressed by increasing the concentration of $\mathrm{B}$ in the leaves to adequate concentrations (Ruiz et al., 1998). PPO activity rises with the $\mathrm{B}$ concentration in the leaf to values of $58 \mathrm{mg} \mathrm{kg}^{-1}$ and $70 \mathrm{mg} \mathrm{kg}^{-1}$ for boric acid and calcium borate, respectively, and decreases with B concentrations of $89 \mathrm{mg} \mathrm{kg}^{-1}$ with the application of calcium borate (Figure 6).

Furthermore, it is worth noting that SOD activity in plants that received the application of $\mathrm{B}$, in the form of calcium borate, was in line with the activity of PPO at the same doses applied. Thus, activity rises as the concentration of $\mathrm{B}$ is elevated (Figure 5A). This fact can be explained by the generation of active quinones during the phenol transformation process by PPO. These active quinones can receive electrons from the light-saturated photosynthetic process, and when in contact with oxygen, the transfer of these electrons and the formation of superoxide occurs, stimulating the activation of the SOD enzyme during antioxidant processes being carried out by the plant (Marschner, 2011; Simón-Grao et al., 2018). For boric acid, the enzyme is already saturated at the lowest dose, which can be a consequence of the rapid absorption of the soluble source, which, as explained, also leads to the generation of ROS.

In this study, we investigated the activity of SOD and PPO enzymes and their correlation with leaf B and $\mathrm{Zn}$ concentration in orange plants with the application of soluble and sparingly soluble sources of these micronutrients. This activity represents biochemical evidence that demonstrates the effect of micronutrient supply from different sources, in addition to that already verified by nutrient concentration and the correlation with the DM of the plants. Further discussion of the generation of ROS, which was not the initial focus of our study, in terms, for example, of quantification of stress products, may be important to explaining effects related to the activities of the enzymes, and could serve as themes for future studies. 


\section{Conclusion}

Our study demonstrated that the foliar supply of B and $\mathrm{Zn}$ to orange plants increases nutrient concentrations in leaves and promotes plant growth, as measured by DM accumulation and LA, similarly with applications of sparingly soluble fertilizer sources /Ca borate, $\mathrm{Zn}$ oxide and $\mathrm{Zn}$ borate) and soluble sources ( $\mathrm{Zn}$ sulfate and boric acid). These responses were consistently correlated with enzymatic activity of the antioxidant system, supporting the foliar application of sparingly soluble sources in the nutritional management of citrus orchards.

\section{Acknowledgments}

The authors thank Nelson Horowitz and Joao Maças from Yara Fertilizer for providing the foliar sources. The authors also acknowledge the CNPq for D.D.M. and R.M.B. research fellowships.

\section{Authors' Contributions}

Conceptualization: Boaretto, R.M.; Mattos Jr., D.; Quaggio, J.A.; Macedo, L.O.; Data acquisition: Macedo, L.O.; Jacobassi, R.; Hippler, F.W.R.; Data analysis: Macedo, L.O.; Jacobassi, R.; Boaretto, R.M.; Mattos Jr., D.; Quaggio, J.A. Design of methodology: Macedo, L.O.; Mattos Jr., D.; Boaretto, R.M.; Software development: Macedo, L.O.; Hippler, F.W.R. Writing and editing: Macedo, L.O.; Boaretto, R.M.; Mattos Jr., D.

\section{References}

Alva, A.K.; Tucker, D.P.H. 1997. Surface decontamination of citrus leaves for macro and micro nutrient analysis. Proceedings of the Florida State Horticultural Society 110: 86-88.

Bataglia, O.C.; Furlani, A.M.C.; Teixeira, J.P.F.; Furlani, P.R.; Gallo, J. 1983. Methods of Chemical Analysis of Plants = Métodos de Análise Química de Plantas. Instituto Agronômico, Campinas, SP, Brazil (in Portuguese).

Bell, R.W.; Dell, B. 2008. Micronutrients for Sustainable Food, Feed, Fibre and Bioenergy Production. International Fertilizer Industry Association, Paris, France.

Bradford, M.M. 1976. A rapid and sensitive method for the quantitation of microgram quantities of protein utilizing the principle of protein-dye binding. Analytical Biochemistry 72: 248-254.

Casano, L.M.; Gomez, L.D.; Lascano, H.R.; González, C.A.; Trippi, V.S. 1997. Inactivation and degradation of CuZn-SOD by active oxygen species in wheat chloroplasts exposed to photo oxidative stress. Plant and Cell Physiology 38: 433-440.

Clapp, J.G. 2009. Let's be careful when defining salt index. Fluid Journal 17: 66-67.

Dawood, S.A.; Meligy, M.S.; El-Hamady, M.M. 2001. Influence of zinc sulfate application on tree leaf and fruit characters of three young citrus varieties grown on slightly alkaline soil. Annals of Agriculture Science 39: 433-447.
Du, Y.; Li, P.; Nguyen A.V.; Xu, Z.P.; Mulligan, D.; Huang, L. 2015. Zinc uptake and distribution in tomato plants in response to foliar supply of $\mathrm{Zn}$ hydroxide-nitrate nanocrystal suspension with controlled $\mathrm{Zn}$ solubility. Journal of Plant Nutrition and Soil Science 178: 722-731.

Eman, A.A.; El-Moneim, A.; El-Migeed, M.A.; Omayma, A.; Ismail, M.M. 2007. GA3 and zinc sprays for improving yield and fruit quality of Washington Navel orange trees grown under sandy soil conditions. Research Journal of Agriculture and Biological Sciences 3: 498-503.

Fageria, N.K.; Filho, M.B.; Moreira, A.; Guimaraes, C.M. 2009. Foliar fertilization of crop plants. Journal of Plant Nutrition 32: 1044-1064.

Fernández, V.; Sotiropoulos, T.; Brown, P.H. 2013. Foliar Fertilisation: Principles and Practices. International Fertilizer Industry Association, Paris, France.

Gomes Jr., R.A.; Moldes, C.; Delite, F.S.; Gratão, P.L.; Lia, P.J.; Mazzafera, P.; Azevedo, R.A. 2006. Antioxidant metabolism of coffee cell suspension cultures in response to cadmium. Chemosphere 65: 1330-1337.

Gratão, P.L.; Polle, A.; Lea, P.J.; Azevedo, R.A. 2005. Making the life of heavy metal-stressed plants a little easier. Functional Plant Biology 32: 481-494.

Gratão, P.L.; Monteiro, C.C.; Antunes, A.M.; Peres, L.E.P.; Azevedo, R.A. 2008. Acquired tolerance of tomato (Lycopersicon esculentum cv. MicroTom) plants to cadmium-induced stress. Annals of Applied Biology 153: 321-333.

Hansch, R.; Mendel, R.R. 2009. Physiological functions of mineral micronutrients $(\mathrm{Cu}, \mathrm{Zn}, \mathrm{Mn}, \mathrm{Fe}, \mathrm{Ni}, \mathrm{Mo}, \mathrm{B}, \mathrm{Cl})$. Current Opinion in Plant Biology 12: 259-266.

Hippler, F.W.R.; Boaretto, R.M.; Quaggio, J.A.; Azevedo, R.A.; Mattos Jr., D. 2015a. Towards soil management with $\mathrm{Zn}$ and Mn: estimates of fertilisation efficacy of Citrus trees. Annals of Applied Biology 166: 484-495.

Hippler, F.W.R.; Boaretto, R.M.; Quaggio, J.A.; Boaretto, A.E.; Abreu Jr., C.H.; Mattos Jr., D. 2015b. Uptake and distribution of soil applied zinc by citrus trees: addressing fertilizer use efficiency with 68Zn labeling. PloS ONE 10: e0116903.

Hippler, F.W.R.; Cipriano, D.O.; Boaretto, R.M.; Quaggio, J.A.; Gaziola, S.A.; Azevedo, R.A.; Mattos Jr., D. 2016. Citrus rootstocks regulate the nutritional status and antioxidant system of trees under copper stress. Environmental and Experimental Botany 130: 42-52.

Hippler, F.W.R.; Petená, G.; Boaretto, R.M.; Quaggio, J.A.; Azevedo, R.A.; Mattos Jr., D. 2018. Mechanisms of copper stress alleviation in Citrus trees after metal uptake by leaves or roots. Environmental Science and Pollution Research 25: 13134-13146.

Hou, W.; Chen, X.; Song, G.; Wang, Q.; Chang, C.C. 2007. Effects of copper and cadmium on heavy metal polluted waterbody restoration by duckweed (Lemna minor). Plant Physiology and Biochemistry 45: 62-69.

Kar, M.; Mishra, D. 1976. Catalase, peroxidase, and polyphenoloxidase activities during rice leaf senescence. Plant Physiology 57: 315319.

Khan, A.S.; Nasir, M.; Malik, A.U.; Basra, S.M.A.; Jaskani, M.J. 2015. Combined application of boron and zinc influence the leaf mineral status, growth, productivity and fruit Quality of 'Kinnow' Mandarin (Citrus nobilis Lour. $\times$ Citrus deliciosa Tenore). Journal of Plant Nutrition 38: 821-838. 
Li, P.; Xu, Z.P.; Hampton, M.; Vu, D.T.; Huang, L.; Rudolph, V.; Nguyen, A.V. 2012. Control preparation of zinc hydroxide nitrate nanocrystals and examination of the chemical and structural stability. The Journal of Physical Chemistry C 116: 10325-10332.

Macedo, L.O.; Boaretto, R.M.; Jacobassi, R.; Carr, N.F.; Quaggio, J.A.; Mattos Jr., D. 2017. Use of sparingly soluble micronutrients sources for citrus production. Citrus R\&T 38: 1-10.

Marschner, P. 2011. Mineral Nutrition of Higher Plants. Academic Press, San Diego, CA, USA.

Mattos Jr., D.; Quaggio, J.A.; Carvalho, S.A.; Abreu, M.F. 1995. Substrates for production of citrus seedlings in containers: characterization of boron toxicity $=$ Substratos para a produção de mudas cítricas em recipientes: caracterização da toxicidade de boro. Laranja 16: 255-262 (in Portuguese).

Mattos Jr., D.; Hippler, F.W.R.; Boaretto, R.M.; Stuchi, E.S.; Quaggio, J.A. 2017. Soil boron fertilization: the role of nutrient sources and rootstocks in Citrus production. Journal of Integrative Agriculture 16: 1609-1616.

Mesquita, G.L.; Zambrosi, F.C.B.; Tanaka, F.A.; Boaretto, R.M.; Quaggio, J.A.; Ribeiro, R.V.; Mattos Jr., D. 2016. Anatomical and physiological responses of citrus trees to varying boron availability are dependent on rootstock. Frontiers in Plant Science 7: 224.

Obreza, T.A.; Morgan, K.T. 2008. Nutrition of Florida Citrus Trees. UF/IFAS SL, Immokalee, FL, USA.

Panda, S.K.; Patra, H.K. 2000. Does chromium (III) produce oxidative damage in excised wheat leaves? Journal of Plant Biology 27: 105-110.

Peryea, F.J. 2006. Phytoavailability of zinc in postbloom zinc sprays applied to golden delicious apple trees. HortTechnology 16: 6065.

Quaggio, J.A.; Mattos Jr., D.; Cantarella, H.; Tank Jr., A. 2003. Boron and zinc application on soil as complement to leaf spray on orange Pera trees. Pesquisa Agropecuária Brasileira 38: 627634 (in Portuguese, with abstract in English).
Quaggio, J.A.; Mattos Jr., D.; Boaretto, R.M. 2010. Citros. v.3. p. 371-409. In: Prochnow, L.I.; Casarin, V.; Stipp, S.R. 2010. Good practices for efficient use of fertilizers $=$ Boas práticas para uso eficiente de fertilizantes. IPNI, Piracicaba, SP, Brazil (in Portuguese).

Razzaq, K.; Khan, A.S.; Malik, A.U.; Shahid, M.; Ullah, S. 2013. Foliar application of zinc influences the leaf mineral status, vegetative and reproductive growth, yield and fruit quality of 'Kinnow'mandarin. Journal of Plant Nutrition 36: 1479-1495.

Ruiz, J.M.; Bretones, G.; Baghour, M.; Ragala, L.; Belakbir, A.; Romero, L. 1998. Relationship between boron and phenolic metabolism in tobacco leaves. Phytochemistry 48: 269-272.

Shenker, M.; Plessner O.E.; Tel-Or, E. 2004. Manganese nutrition effects on tomato growth, chlorophyll concentration, and superoxide dismutase activity. Journal of Plant Physiology 161: 197-202.

Simón-Grao, S.; Nieves, M.; Martínez-Nicolás, J.J.; Cámara-Zapata, J.M.; Alfosea-Simón, M.; García-Sánchez, F. 2018. Response of three citrus genotypes used as rootstocks grown under boron excess conditions. Ecotoxicology and Environmental Safety 159: 10-19.

Tariq, M.; Sharif, M.; Shah, Z.; Khan, R. 2007. Effect of foliar application of micronutrients on the yield and quality of sweet orange (Citrus sinensis L.). Pakistan Journal of Biological Sciences 10: $1823-1828$.

Ullah, S.; Khan, A.S.; Malik, A.U.; Afzal, I.; Shahid, M.; Razzaq, K. 2012. Foliar application of boron influences the leaf mineral status, vegetative and reproductive growth, yield and fruit quality of 'Kinnow' mandarin (Citrus reticulata Blanco.). Journal of Plant Nutrition 35: 2067-2079.

Wang, N.; Yang, C.; Pan, Z.; Liu, Y.; Peng, S.A. 2015. Boron deficiency in woody plants: various responses and tolerance mechanisms. Frontiers in Plant Science 6: 916.

Westfall, D.G.; Amrani, M.; Peterson, G.A. 1999. Water-solubility of zinc fertilizer: does it matter? Better Crops 83: 18-20. 